\title{
Oat cell carcinoma of bronchus presenting as an acute psychiatric illness in young women
}

\author{
S. H. RALSTON \\ M.B., Ch.B., M.R.C.P. \\ I. FOGELMAN \\ M.B., Ch.B., M.R.C.P. \\ G. D. O. LOWE \\ M.B., Ch.B., M.R.C.P. \\ University Department of Medicine, Glasgow Royal Informary, Glasgow G4 OSF
}

\begin{abstract}
Summary
Two young women are described who presented with an acute psychiatric illness, due to the metabolic effects of inappropriate anti-diuretic hormone (ADH) secretion. In both patients symptoms were promptly abolished by correction of the biochemical disturbance and subsequent investigations revealed hitherto occult oat cell carcinoma of bronchus. These patients demonstrate the value of routine laboratory investigations in all patients with an acute psychiatric illness and illustrate that bronchial carcinoma must be considered in patients of all age groups presenting with the syndrome of inappropriate ADH secretion.
\end{abstract}

\section{Case 1}

A 36-year-old woman, previously healthy, presented to a psychiatric unit with an acute illness characterized by withdrawal, psychomotor retardation, character change and hallucinations both auditory and visual. On history taking and full physical examination there was no suspicion of organic disease although it was noted that she smoked about 30 cigarettes per day. A tentative diagnosis of catatonic schizophrenia was made, and treatment with chlorpromazine commenced. Over the ensuing 2 months the patient's mental state improved little, despite the addition of tricyclic anti-depressant drugs to her therapeutic regime.

She was finally transferred to the medical wards at the end of this period because pallor was noted and a blood count had revealed haemoglobin $(\mathrm{Hb})$ to be reduced at $11.0 \mathrm{~g} / \mathrm{dl}$. Further investigations at that time were as follows: $\mathrm{Na} 121 \mathrm{mmol} / 1, \mathrm{~K} 4.1 \mathrm{mmol} / \mathrm{l}$, Cl $82 \mathrm{mmol} / 1, \mathrm{HCO}_{3} 22 \mathrm{mmol} / 1$, urea $3.1 \mathrm{mmol} / 1$, plasma osmolality $266 \mathrm{mmol} / \mathrm{l}$, urine osmolality 426 mmol/l, 24-hr urinary sodium $130 \mathrm{mmol}$, plasma antidiuretic hormone (ADH) $19.5 \mathrm{pg} / \mathrm{dl}$ (normal 3-12). Chest $X$-ray showed an opacity in the right upper lobe. Bronchoscopy confirmed the presence of $\circlearrowleft$ an oat cell carcinoma in the right upper lobe $N$ bronchus. On correction of the biochemical abnor- 을 malities by water restriction and oral demeclocycline, symptoms were completely abolished.

\section{Case 2}

A 38-year-old woman, previously healthy, pre sented to our medical unit with an acute illnes characterized by character change, aggressive be haviour with paranoid features and visual hallucin tions. The patient was fully orientated and there was no clouding of consciousness. On history taking and full physical examination there was no suspicion of organic disease, although it was noted that she smoked 20 cigarettes per day. A diagnosis of acute schizophrenia was tentatively made and the patient was sedated with chlorpromazine pending a psychiatric referral. Routine investigations were performed and the results are as follows: $\mathrm{Na} 114 \mathrm{mmol} / \mathrm{l}$, $\mathrm{K} 3.2 \mathrm{mmol} / \mathrm{l}, \mathrm{Cl} 86 \mathrm{mmol} / 1, \mathrm{HCO}_{3} 22 \mathrm{mmol} / 1$, urea $2.0 \mathrm{mmol} / \mathrm{l}, \mathrm{Hb} 11.7 \mathrm{~g} / \mathrm{dl}$, plasma osmolality 253 $\mathrm{mmol} / 1$, urine osmolality $632 \mathrm{mmol} / 1,24-\mathrm{hr}$ urinary sodium $148 \mathrm{mmol}$ ADH level $17.0 \mathrm{pg} / 1$. Chest X-ray showed an opacity and partial collapse of the right lower lobe. Bronchoscopy revealed an oat cell carcinoma in the right lower lobe bronchus. On correction of the biochemical abnormalities by water restriction and oral demeclocycline, symptoms were successfully abolished.

\section{Discussion}

We have described two young women who presented with an acute psychiatric illness as the initial manifestation of oat cell carcinoma of bronchus. On investigation severe hyponatraemia was discovered with inappropriately raised levels of $\mathrm{ADH}$ 
in the peripheral blood. Symptoms were promptly abolished by correction of the underlying metabolic abnormality by water restriction and oral demeclocycline.

Although a psychiatric illness may occasionally herald the appearance of an occult bronchial tumour, this is rare, and has been most often ascribed to a carcinomatous encephalopathy, without metabolic upset (Morton, Mabashi and Grimes 1966).

The presentation of our patients is of interest on three counts. Firstly, oat cell carcinoma is an exceedingly rare tumour in this age group. It is estimated that $1-4 \%$ of patients with bronchogenic carcinoma are aged under 40 years (Fraser and Pare, 1978; Weiss, 1974). Of these patients only $0.08-0.32 \%$ may be expected to have a lesion of the oat cell type (Putnam, 1977). Secondly, the syndrome of inappropriate ADH secretion, although well recognized in association with oat cell carcinoma, is seldom a presenting feature of the illness (Fraser and Pare, 1978). Finally, psychiatric symptoms are unusual in the syndrome of inappropriate ADH secretion which is typically associated with neurological disorders such as clouding of consciousness, confusion, convulsions and coma (DeTroyer and Demenet, 1976).
Although the practice of performing routine laboratory investigations in young, ostensibly healthy patients with psychiatric illness has recently been questioned (Hughes and Barraclough, 1980) our experience would suggest that routine biochemistry and radiology are justified in these circumstances. It is also apparent that bronchogenic carcinoma must be rigorously excluded in patients of any age presenting with the syndrome of inappropriate ADH secretion.

\section{References}

DeTroyer, A . \& Demenet, J . C . (1977) Clinical, biological and pathogenic features of the syndrome of inappropriate secretion of antidiuretic hormone. Quarterly Journal of Medicine, 45, 521.

FRASER, R . G . \& PARE, J.A.P. (1978) Diagnosis of Diseases of the Chest, 2nd edn, p. 1002, p. 1043. W. B. Saunders, Philadelphia.

HUGHES, J . \& BARRACLOUGH, B . M . (1980) Value of routine chest radiography of psychiatric patients. British Medical Journal, 281, 1461.

Morton, D . L . , MABashi, H . H . \& Grimes, O . F . (1966) Nonmetastatic neurological complications of bronchogenic carcinoma. The carcinomatous neuromyopathies. Journal of Thoracic and Cardiovascular Surgery, 51, 14.

PUTNAM, J . S . (1977) Lung carcinoma in young adults. Journal of the American Medical Association, 238, 35.

WEISS, W . (1974) Operative mortality and five year survival rates in men with bronchial carcinoma. Chest, 66, 483. 